\title{
Desclassificação de Todas as Propostas na Licitação. Interpretação do Artigo 48, § 3으, da Lei Federal no 8.666/93
}

Flávio de Araújo Willeman'

\section{Introdução}

Após a superação do método paternalista ${ }^{2}$ de administração pública, e, de alguma forma, do avanço do método burocrático ${ }^{3}$ de administrar para a atuação gerencial do Estado brasileiro, dúvidas não restam de que mudou o paradigma da gestão da coisa pública.

\footnotetext{
1 Procurador do Estado do Rio de Janeiro e Advogado. Mestre em Direito pela Universidade Candido Mendes. Professor dos cursos de graduaçāo e pós-graduação da Universidade Candido Mendes. Professor dos cursos de pós-graduação da Escola de Direito do Rio de Janeiro, da Fundação Getúlio Vargas - FGV e da Universidade Federal Fluminense - UFF. Professor do Curso CEJ, preparatório para concursos públicos no Estado do Rio de Janeiro. Autor do livro. Responsabilidade Civil das Agências Reguladoras, pela editora Lumen Juris.

2 Segundo Cláudio Eduardo Regis de Oliveira, "a administração burocrática apresenta-se como evidente progresso diante da administraçāo patrimonialista, caracteristica do feudalismo e dos regimes absolutistas e despóticos, marcada pelo poder ilimitado do soberano e pela confusão entre a sua propriedade particular e o patrimônio do Estado (res publica). [...]. Outra característica da forma administrativa patrimonialista, predominante no período feudal, era a chamada dominação estamental, a apropriação dos cargos administrativos por determinadas camadas sociais. Os servidores viviam na mais completa dependência do senhor, que os convocava e dispensava sem qualquer critério preestabelecido, em tempos de paz ou de guerra". Administraçāo Gerencial \& a Reforma Administrativa no Brasil. Curitiba: Juruá, 2002, p. 54-55.

3 Sobre o método burocrático de administraçāo, mencionem-se novamente as palavras de Cláudio Eduardo Regis de Oliveira: "[...]. Em oposif̧ão (à administração paternalista), a administraf̧ão burocrática demonstra ser muito mais avançada, ao possibilitar um exercício impessoal, programado e continuado do poder, com uma competência delimitada pela lei, onde os deveres e os serviços săo determinados em virtude de uma distribuif̧āo de funçōes, com prévia atribuição de poderes necessários ao seu exercício e fixaçāo estrita dos meios coativos necessánios à obediência." Administração Gerencial \& a Reforma Administrativa no Brasil. Ob. cit., p. 53-55.
} 
Com a vigência da Constituição Federal de 1988 prima-se pela administração pública consensual, de resultados, por colaboração de parceiros privados, sem, contudo, desrespeitarem-se os princípios jurídicos expressos e reconhecidos pela Carta Magna e pelas leis infraconstitucionais. Reinterpreta-se, sobretudo, o vetusto princípio da supremacia do interesse público sobre o interesse particular à luz dos direitos fundamentais, ${ }^{4}$ máxime em prol da noção de atendimento da dignidade humana. MARÇAL JUSTEN FILHO chega a afirmar que a personificação do direito administrativo propicia reconhecer que a administração pública não é um valor em si mesmo, mas uma atividade que deve se guiar pela democracia e pelo respeito aos direitos fundamentais, de modo a atender, sobretudo, os interesses de minorias. ${ }^{5}$

Com efeito, a mudança de paradigma do direito administrativo e, assim, da administração pública, se reflete, por certo, nos contratos administrativos, sobretudo naqueles típicos, em que tradicionalmente se confere à administração pública contratante algumas prerrogativas não extensíveis aos contratados.

Para melhor aclarar este novo modo de interpretar os contratos administrativos, não se pode olvidar o conhecimento convencional, adiante-se, hoje em franca fase de reformulação, no sentido de que as diferenças do contrato administrativo típico para os demais contratos postos à disposição do Estado e da sociedade civil residem nos seguintes fatores: (a) no respeito aos princípios da legalidade, eficiência, impessoalidade, economicidade, isonomia e competitividade; (b) na submissão de um regime jurídico primordialmente de direito público, e (c) na conferência à administração pública de cláusulas de privilégio ${ }^{6}$ (ou exorbitantes) que, dentro da relação jurídico-contratual, a colocam em posição de superioridade jurídica frente ao contratado.

$\mathrm{Na}$ linha da tese da revisão dos paradigmas do direito administrativo, conforme acima se mencionou, DIOGO DE FIGUEIREDO MOREIRA NETO propõe uma nova interpretação das cláusulas de privilégio conferidas à administração pública em contratos administrativos típicos, de modo a reinterpretá-las à luz dos novos parâmetros da contratação pública, quais sejam: "a preeminência dos direitos fundamentais; a exigência de legitimidade; a necessidade de assegurar a competitividade; $a$ indispensabilidade de criar e aperfeiçoar as tecnologias; a importância da publicidade $e$ da visibilidade da atuação pública; a obrigatoriedade da motivação e a inafastabilidade de controles multimodais, cada vez mais especializados".?

\footnotetext{
4 Mencione-se a respeito o valioso trabalho de Gustavo Binenbojm: Da Supremacia do Interesse Público ao Dever de Proporcionalidade. Um Novo Paradigma para o Direito Administrativo. Direito Administrativo - Série Direito em Foco. Coord. Valter Shuenquener de Araújo. Niterói: Ímpetos, 2005, p. 79-114.

JUSTEN FILHO, Marçal. Curso de Direito Administrativo. São Paulo: Malheiros, 2005, p. 46.

6 As cláusulas de privilégio estão inseridas no art. 58 da Lei Federal no 8.666/93.

7 MOREIRA NETO, Diogo de Figueiredo. O Futuro das Cláusulas Exorbitantes nos Contratos Administrativos. Revista de Direito da Associação dos Procuradores do Novo Estado do Rio de Janeiro -Parcerias Público Privadas. Coord. Flávio Amaral Garcia. Rio de Janeiro: Lumen Juris, 2005,
} 
Pois bem. Diante desses novos influxos da doutrina para reinterpretar algumas formas de atuação da administração pública não se pode deixar de lado a necessidade de inserir neste contexto, em alguns casos específicos do tema da contratação pública, uma maior efetividade do princípio do aproveitamento dos atos processuais que compõem o procedimento licitatório - prévio à contratação -, de modo a se perquirir, conseqüentemente, maior efetividade aos princípios da eficiência e economicidade, que, em última análise, informarão o atendimento ou não do interesse público.

Dentro desta perspectiva é que se propõe enfrentar a discussão quanto à interpretação e aplicação do artigo 48, $\$ 3^{\text {o }}$, da Lei Federal nº 8.666/93.

\section{O procedimento licitatório e a interpretação do artigo $48, \S 3^{\circ}$, da Lei Federal $n^{\circ}$ 8.666/93}

A Constituição Federal de 1988, no artigo 37, inciso XXI, determina que, ressalvados os casos previstos na legislação, as contratações de obras, serviços, compras e alienaçōes por parte da Administração Pública devem ser precedidas de procedimento licitatório, em que se assegure igualdade de condiçōes a todos os concorrentes, de modo a permitir a seleção da proposta mais vantajosa para contratar com o Poder Público, de acordo com o critério de julgamento estabelecido na lei e adotado pelo edital, que, geralmente, leva em consideração o menor preço, a melhor técnica, ou a conjugação do menor preço com a melhor técnica, ou ainda, em caso de licitação para alienação de coisas ou para concessão de direito real de uso, do melhor lance ou oferta. ${ }^{8}$

A Lei Geral de Licitações - Lei Federal nº 8.666/93 - traça as regras básicas do procedimento licitatório, estabelecendo alguns princípios jurídicos que o norteiam (art. $3^{\circ}$ ), dentre os quais se destacam a legalidade, a impessoalidade, a moralidade, a igualdade, a publicidade, a probidade administrativa, a vinculação ao instrumento convocatório, o julgamento objetivo das propostas, admitindo a aplicação de outros que lhe são correlatos, ${ }^{9}$ fato que, por certo, não exclui a incidência dos princípios do aproveitamento, sempre que possível, dos atos válidos que compóem o procedimento licitatório, da economicidade, eficiência e da razoabilidade.

O Estatuto acima mencionado cuida, como não poderia deixar de ser, da apresentação das propostas, da habilitação jurídica, técnica e financeira dos licitantes,

v. 17, p. 3-21, p. 13. Anote-se também o trabalho do Desembargador Jessé Torres Pereira Junior, cujo título é: Notas Acerca das Repercussōes do Novo Código Civil sobre os Contratos Administrativos. Direito Administrativo - Série Direito em Foco. Coord. Valter Shuenquener de Araújo. Niterói: Ímpetos, 2005, p. 115-136.

8 Confira-se, a propósito, o artigo $45, \$ 1^{\circ}$, inciso I, da Lei Federal n⿳0 8.666/93.

9 Para uma análise pormenorizada dos princípios explícitos e reconhecidos inerentes ao procedimento licitatório, recomenda-se a leitura da obra de Marcos Juruena Villela Souto, Direito Administrativo Contratual. Licitações e Contratos Administrativos. Rio de Janeiro: Lumen Juris, 2004, p. 5-20. 
e, também, dos critérios e métodos de julgamentos das propostas, tudo com o fim, repita-se, de selecionar, à luz dos princípios jurídicos antes enunciados a proposta mais vantajosa para contratar com o Poder Público.

A Lei Federal $n^{\circ} 8.666 / 93$ previu, no artigo 48, incisos I e II, e no $\$ 3^{\circ}$, hipóteses de desclassificação parcial e total das propostas apresentadas pelos licitantes, estabelecendo a imediata conseqüência que pode ser adotada pelo administrador público. Confira-se a redação do dispositivo legal citado:

“Art. 48. Serāo desclassificadas:

I - as propostas que não atendam às exigências do ato convocatório da licitação;

II - propostas com valor global superior ao limite estabelecido ou com preços manifestamente inexeqüíveis, assim considerados aqueles que não venham a ter demonstrada sua viabilidade através de documentação que comprove que os custos dos insumos são coerentes com os de mercado e que os coeficientes de produtividade são compatíveis com a execução do objeto do contrato, condiçōes estas necessariamente especificadas no ato convocatório da licitação.

[...]

$\int 3^{\text {o }}$ Quando todos os licitantes forem inabilitados ou todas as propostas forem desclassificadas, a administração poderá fixar aos licitantes o prazo de oito dias úteis para a apresentação de nova documentação ou de outras propostas escoimadas das causas referidas neste artigo, facultada, no caso de convite, a redução deste prazo para três dias úteis." Grifamos.

Observe-se, assim, que o Estatuto das Licitações e Contratos elencou taxativamente as hipóteses em que as propostas dos licitantes poderão ser desclassificadas.

Em sendo parcial a desclassificação, o certame continua com os licitantes habilitados e classificados. Se todos os licitantes forem desclassificados, aplica-se a regra enunciada pelo $\$ 3^{\circ}$ do artigo 48 da Lei Federal $n^{\circ}$ 8.666/93, que vem gerando fecundas discussōes em sede doutrinária e jurisprudencial.

Em primeiro lugar, deve-se dizer que o $\$ 3^{\circ}$ do artigo 48 , acima transcrito, encerra à Administração Pública uma faculdade e não um dever. Isto é, ao administrador público caberá, à luz de critérios de conveniência e oportunidade, decidir, fundamentadamente, se, diante da desclassificação de todas as propostas, realizará outro certame ou se, ao contrário, buscará escoimar os vícios das propostas apresentadas, aproveitando-se, assim, o procedimento já em curso.

Por outro lado, torna-se importante observar, desde logo, que o artigo 48, \$ 3º, da Lei Geral de Licitaçōes, enuncia um importante objetivo a ser tutelado 
pela Administração Pública: garantir a celeridade e a economia dos atos que compõem um procedimento licitatório. Estes são os nortes que devem guiar a correta interpretação do dispositivo legal mencionado.

Porém, antes de se discutir a interpretação do $₫ 3^{\circ}$ do artigo 48 da Lei de Licitaçōes, necessário saber se este dispositivo está ou não de acordo com a Constituiçāo da República de 1988.

Parte da doutrina tem sustentado ser inconstitucional o $\$ 3^{\circ}$ do artigo 48 da Lei Federal $n^{0} 8.666 / 93$, trazido ao ordenamento jurídico pela Lei Federal $n^{9}$ 9.648/98, sob o argumento de que vulnera os princípios da competitividade, moralidade e isonomia. Argumenta-se que, diante da desclassificação de todos os licitantes, a única soluçāo possível ao administrador público seria a renovação do procedimento licitatório, repensando-se, inclusive, os termos do instrumento convocatório. Neste sentido, manifesta-se MARÇAL JUSTEN FILHO:

"A regra infringe princípios constitucionais e não pode ser considerada válida. Uma vez verificada a existência de defeitos na documentação ou na proposta de todos os licitantes, a única solução cabível seria renovar o procedimento licitatório. Em princípio, a Administração deverá renovar a licitação, reavaliando inclusive os termos do instrumento convocatório (que, por excessivas sumariedade ou complexidade, pode ter sido fator relevante para a desclassificação). Ou seja, o dispositivo transforma os anteriores licitantes em titulares de faculdade incompatível com regras e princípios constitucionais. [...].

Se todas as propostas foram desclassificadas, não há fundamento jurídico para restringir a apresentação de novas propostas apenas aos anteriores participantes. Essa restrição é indevida e ofende os princípios da isonomia, da moralidade e da competitividade. Impede indevida e injustificadamente a participação de interessados no procedimento licitatório."10

Com a venia devida, não há falar-se em inconstitucionalidade do artigo $48, \S$ $3^{\circ}$, da Lei Federal $n^{\circ}$ 8.666/93. Não há ofensa aos princípios da moralidade, impessoalidade e isonomia. Explica-se a razão deste posicionamento.

Conforme já mencionado, o procedimento licitatório destina-se à escolha da proposta mais vantajosa para contratar com a Administração Pública e deve respeitar o princípio da isonomia entre os competidores, bem como a paridade de regras, necessária à garantia da intangibilidade do princípio da competitividade.

10 JUSTEN FILHO, Marçal. Comentários à Lei de Licitaçōes e Contratos Administrativos. 9. ed. São Paulo: Dialética, 2002, p. 435-436. Digno salientar que o autor citado, na mesma obra, na página 436, enfrenta a interpretação do dispositivo comentado, caso o mesmo seja admitido como constitucional. Voltar-se-á às suas conclusōes mais adiante. 
Contudo, os princípios acima mencionados não podem ser interpretados de modo a inviabilizar ou a trazer formalismos exagerados ao procedimento licitatório, circunstância que acabaria por malferir a Constituição Federal, mormente o desiderato inserto no artigo 37, inciso XXI, e sobretudo os princípios da economicidade, razoabilidade e eficiência. Formalismo é a exacerbação da formalidade e não deve mais ser admitido no novo perfil de atuação da Administração Pública, que, conforme já se anunciou, busca a substituição do modelo burocrático (de forte controle interno) pelo modelo gerencial ou consensual de administração pública, onde se privilegia o resultado. $O$ formalismo, em última análise, pode inquinar o ato ou o procedimento de ilegalidade, em razão do desvio de finalidade e por violação à regra de razoabilidade. ${ }^{11}$

Com efeito, desde que os vícios existentes em todas as propostas desclassificadas sejam razoavelmente sanáveis e que tenha havido ampla publicidade do certame (nos termos da modalidade de licitação escolhida), não há falar-se em violação dos princípios da competitividade e isonomia, uma vez que todos aqueles que desejavam contratar com a Administração Pública se habilitaram no procedimento e todos aqueles que foram desclassificados terão, segundo o artigo $48, \S 3^{\circ}$, da Lei de Licitações, a possibilidade de escoimar de suas propostas os vícios que as maculam.

Importante notar que o $\$ 3^{\circ}$ do artigo 48 da Lei de Licitaçōes respeita o princípio da isonomia, na medida em que não impōe discriminação prévia ou posterior a possíveis licitantes e àqueles que se aventuraram a participar do certame e, por conseqüência, não discrimina qualquer proposta desclassificada, na medida em que faculta a todos os participantes a possibilidade de afastar os vícios detectados em suas propostas.

O dispositivo contido no artigo $48, \mathbb{3} 3^{\circ}$, da Lei Federal $n^{\circ}$ 8.666/93 não é, assim, inconstitucional e, ao contrário, atende ao princípio constitucional da razoabilidade $^{12}$, diante da dicção do artigo 37, inciso XXI, da CRFB/88; atende, também,

11 Sobre a idéia de "formalismo moderado", sobretudo em procedimentos concorrenciais, mencionese a doutrina de Mônica Martins Toscano Simōes: " $E$ de se registrar ser preferencial a expressāo formalismo moderado a informalismo, pois esta poderia levar à absurda idéia de que não há qualquer exigência formal a ser observada no bojo do processo administrativo. $O$ certo é que tais exigências devem ser atenuadas, mas não a ponto de pôr em risco a segurança processual.

[...]

Contudo, é de se alertar que a aplicação do formalismo moderado nos processos concorrenciais só é permitido com relaçāo a formalidades não essenciais - isto é, aquelas que nāo comprometem sua finalidade; é óbvio que a atenuação das formalidades não pode ser invocada para afastar nulidades. A razoabilidade deve guiar a Administração na aplicação do princípio do formalismo moderado em processos concorrenciais" (O Processo Administrativo e a Invalidade de Atos Viciados. Coleção Temas de Direito Administrativo nº 10. São Paulo: Malheiros, 2004, p. 100-101). Grifamos.

12 Comentando a incidência do princípio da razoabilidade nos processos administrativos, importante se mostra a doutrina de José dos Santos Carvalho Filho, verbis: "Aqui se tem em mira exigir que as açōes administrativas guardem compatibilidade entre os fundamentos e o objetivo do ato, ou seja, sejam dotados de congruência entre o motivo $e$ o objeto, na feliz referência de MARCELO CAETANO. O objetivo do princípio da razoabilidade é a relą̧āo triangular que se institui entre motivo. meio e fim e serve para verificar a coerência das condutas estatais. Não se trata de mero juizo de valor pessoal - este irrelevante para a Administrą̧ão. Cuida-se, 
aos princípios da realidade, economicidade $e$ do aproveitamento dos atos válidos que compõem um procedimento administrativo. ${ }^{13}$

Conforme já se adiantou, o artigo $48, \$ 3^{\circ}$, da Lei Federal $n^{\circ} 8.666 / 93$ prestigia e impōe efetividade aos princípios da economicidade, do formalismo moderado $e$ eficiência, que apregoam, na medida do possível, a desburocratização da atividade administrativa com medidas que, sem afetar o princípio da estrita legalidade, logre obter resultados positivos, legítimos e válidos ao menor custo possível, atendo-se, assim, ao interesse público aferido no caso concreto. Mencionem-se, neste sentido, as liçōes de SERGIO FERRAZ e ADILSON ABREU DALLARI, verbis:

"A Emenda Constitucional 19, de 4.6.1998, conhecida como 'Emenda da Reforma Administrativa', trouxe profundas modificações na Administração Pública brasileira. O propósito fundamental dessa reforma era a substituição do antigo modelo burocrático, caracterizada pelo controle rigoroso dos procedimentos, pelo novo modelo gerencial, no qual são abrandados os controles de procedimentos e incrementados os controles de resultados. Essa linha de pensamento - esse novo valor afirmado pela Constituição - não pode ser ignorada pelo intérprete e aplicador da lei.

[...]

Isso significa que é preciso superar concepções puramente burocráticas ou meramente formalistas, dando-se maior ênfase ao exame da legitimidade, da economicidade e da razoabilidade, em benefício da eficiência. Não basta ao administrador demonstrar que agiu bem, em estrita conformidade com a lei; sem se divorciar da legalidade (que nāo se confunde com a estrita legalidade); cabe a ele evidenciar que caminhou no sentido da obtenção dos melhores resultados." 14 Grifamos.

Por certo, caberá ao administrador público, motivadamente, verificar se o interesse público estará melhor atendido renovando-se o procedimento licitatório, ou

isto sim, de concreta observaçāo sobre os elementos básicos da conduta administrativa, ou seja, de constatar se a conduta é compativel com o fim legal (adequaçāo); se é necessária, inexistindo outro meio menos gravoso para alcançar o fim (exigibilidade); e se as vantagens perseguidas superam as desvantagens (proporcionalidade em sentido estrito). Aplicado ao processo administrativo, o princípio implica a idéia de que os atos que o compóem devem refletir os elementos da adequação, necessidade e proporcionalidade, todos integrantes do sentido de razoabilidade" (Processo Administrativo. Direito Administrativo. Série Direito em Foco. Coord. Valter Shuenquener de Araújo. Niterói: Ímpetos, 2005. p. 139-168, p. 158-159).

13 Apesar de não se estar a falar de nulidade, aplicar-se-iam, ao procedimento licitatório, com as devidas ressalvas e proporçôes, as regras insertas nos artigos 244 e 250 do CPC, de aproveitamento de atos válidos dentro do processo (ou do procedimento), com fundamento no artigo 54 da Lei Federal $\mathbf{n}^{9}$ 8.666/93 e, especificamente no Estado do Rio de Janeiro, no artigo 368 da Constituição Estadual de 1989 (Art. 368. Na aplicação, integração e interpretação das leis, decretos e outros atos normativos estaduais, res. salvada a existência de norma estadual específica, observar-se-ão os princípios vigentes quanto às da Constituição $e$ das leis federais), recentemente declarado constitucional pelo STF, quando do julgamento da ADI 246.

i4 FERRAZ, Sérgio; DALlARI, Adilson Abreu. Processo Administrativo. 1. ed. $2^{2}$ tiragem. São Paulo: Malheiros, 2002, p. 77-78. 
simplesmente determinando a todos os licitantes desclassificados que excluam de suas propostas os vícios sanáveis que elas apresentam, desde que não relacionados ao preço final, e, assim, valendo-se da regra do aproveitamento dos atos válidos já praticados no processo licitatório, determinar que se prossiga no certame.

Assentada a constitucionalidade do artigo 48 , $₫ 3^{\circ}$, da Lei Geral de Licitações, passa-se a examinar o seu conteúdo e alcance.

Da redação do artigo $48, \$ 3^{\circ}$, da Lei Federal $n^{\circ} 8.666 / 93$ pode-se chegar a duas hipóteses em que se permite à Comissão de Licitação desclassificar todas as propostas habilitadas e determinar, no prazo peremptório de 8 (oito) dias, ${ }^{15}$ a sanatória dos vícios que as maculam. A primeira delas, contida no inciso I do artigo 48 , diz respeito a meros erros formais quando as propostas não atendam a exigências contidas no edital de convocação. A segunda diz respeito a problemas com os preços ou valores contidos nas propostas.

Note-se, então, que o artigo 48, incisos I e II da Lei Federal no 8.666/93, encerra duas situações diferentes, que, por certo, reclamam soluções diferentes quando de sua interpretação e aplicação da regra prevista no seu $₫ 3^{\circ}$.

No caso do inciso II do artigo 48 da Lei de Licitaçōes - que revela problemas com os preşos ofertados -, a interpretação do $\$ 3^{\circ}$ do artigo 48 da Lei Federal $n^{\circ}$ $8.666 / 93$, com o devido respeito aos que pensam de forma contrária, por certo, reclamará a realização de outro certame licitatório ou, à discricionariedade da Administração Pública, a apresentação de novos envelopes de preços, contendo novos valores.

A segunda opção apresentada no parágrafo anterior não será observada, necessariamente, no caso de as desclassificações das propostas ocorrerem ao fundamento do inciso I do artigo 48; isto é, quando as propostas desclassificadas estiverem eivadas de meros erros materiais (de forma) ou não atenderem a exigências contidas no edital de convocação.

Afirma-se isto porque, no caso do inciso I do artigo 48 da Lei de Licitações, a interpretação do seu $₫ 3^{\circ}$ conduz a resultado diverso da emprestada ao inciso II, uma vez que deverão ser "escoimadas" das propostas apresentadas pelos licitantes

15 A xxpressão é de Jessé Torres Pereira Júnior, que conclui ser peremptório o prazo de 8 (oito) dias previsto no artigo 48 da Lei Geral de Licitaçōes, verbis: "Indaga-se se o prazo é peremptório (insubstituivel por outro, menor ou maior) ou dilatório (reduzivel ou ampliável, ao critério da Comissão ou a requerimento de licitante). Os prazos assinalados na Lei $n^{\circ} 8.666 / 93$ inserem-se no contexto de normas cogentes, vale dizer, inafastáveis pela vontade dos interessados, porque destinadas a proteger o interesse público. Como normas de ordem pública, hão de ser obedecidas estritamente. No caso em tela, o prazo é de oito dias úteis; quisesse a lei deixar ao nuto administrativo a fixą̧āo de outro, teria dito que seria de até oito dias (como no art. 53, 53 \%; assim não ofez, estabelecendo-o em oito dias úteis exatos." Comentários à Lei de Licitações e Contratações da Administração Pública. $6^{*}$ ed. Rio de Janeiro: Renovar, 2003, p. 502. Registre-se, apenas, que entendemos que, antes da abertura do prazo peremptório de 8 (oito) dias para que os licitantes escoimem de suas propostas os vícios que a maculam, deve a Comissão de Licitação abrir o prazo de cinco dias para apresentação pelos licitantes de eventual recurso contra a decisão de inabilitaçāo ou desclassificação de todas as propostas. 
somente os erros materiais que as viciam, sem que, em regra, nova proposta de preço seja apresentada, sob pena de se converter o procedimento em verdadeiro leilão, o que não se pode permitir. Neste sentido, ao que parece, apresenta-se o entendimento de MARÇAL JUSTEN FILHO, verbis:

"Se for admitida a constitucionalidade do art. $48, \uparrow 3^{\circ}$, não será permissível à Administração utilizar essa faculdade para desnaturar a licitação. Imaginando ser possível obter propostas mais satisfatórias, a Administração poderia ser tentada a promover arbitrariamente a desclassificação de todas as propostas. Forçaria os licitantes a rebaixar as exigências através da apresentação de novas propostas. A opção do art. 48, $3^{\circ}$, transformaria a licitação numa espécie de leilão. Os licitantes, tomando conhecimento das propostas existentes, elevariam as vantagens ofertadas à Administração. Ora, o leilão não foi admitido para hipótese em que a Administração bem entender." ${ }^{16}$ Grifamos.

\section{Por igual, mostra-se a doutrina de CARLOS ARI SUNDFELD:}

"No sistema legal brasileiro vigora, salvo duas exceçōes expressas, a regra da imutabilidade das propostas financeiras no curso do procedimento licitatório. A época adequada para a elaboração da oferta é a que vai do chamamento ao certame [...] até a data da chamada abertura, quando se dá a inscrição do licitante com a entrega da proposta. Ultrapassado esse momento, ela não pode mais ser alterada. [...] $\mathrm{O}$ antigo art. 48, parágrafo único da Lei $n^{\circ} 8.666 / 93$, tornou-se $\$ 3^{\circ}$ do mesmo artigo com o advento da Lei $n^{\circ}$ 9.648/98. [...]. Nesse caso, entretanto, é imporrtante que o ente licitante identifique - restringindo o escopo da escoima - os aspectos que necessitam de retificação ou supressão na proposta, impedindo assim a apresentação de verdadeiras novas propostas, caso o aspecto de retificação não tenha repercussão quanto ao conteúdo econômico da proposta original." 17

16 JUSTEN FILHO, Marçal. Comentários à Lei de Licitações e Contratos Administrativos. 9. ed. São Paulo: Dialética, 2002, p. 436. No mesmo sentido, isto é, não admitindo a livre alteraçāo de proposta viciada em processo licitatório, mostra a doutrina de Fábio Barbalho Leite: "Por estas linhas, chega-se à seguinte constatação: a contemporização do formalismo licitatório (leia-se: vinculafão ao instrumento convocatório) não pode importar em livre alteração de conteúdo da proposta viciada, entendendose conteúdo como a caracterização do objeto ofertado e do significado econômico dessa proposta." Tal livre alterafẵo, como visto, implicaria ou na intromissão da Comissão de Julgamento da Licitação na intimidade da proposta comercial (aquele núcleo da proposta depende de decisão do proponente) ou no ensejo ao proponente de reformular sua proposta comercial quando descerradas as demais. Uma ou outra hipótese desdenharia princípios da licitação como isonomia, vinculação ao instrumento editalício, seriedade e certeza da proposta e moralidade administrativa. De permeio, estar-se-ia inclusive incorrendo em conduta qualificável como 'ato de improbidade administrativa'. A Mitigação do Formalismo no Julgamento da Habilitação e das Propostas em Licitaçōes. Revista de Direito Administrativo - RDA n² 236. p. 175-204, abr./jun. 2004, editora Renovar, p. 197.

17 SUNDFELD, Carlos Ari. O Formalismo no Procedimento Licitatório. Revista da Procuradoria Geral da República. São Paulo: Revista dos Tribunais, n² 5. 11-12). Grifamos. 
Assim, caso os vícios das propostas desclassificadas não digan respeito ao preço propriamente dito, ao valor nelas contido, ou a exigências formais que, de alguma forma, influenciam no preço, mas, tão-somente, a vícios materiais que digam respeito ao edital de convocação, deverão os licitantes apenas "escoimar" os defeitos dela constantes, no prazo de oito dias, sem, contudo, apresentar nova proposta de preço.

A razão para adoção do posicionamento supra pode ser extraída da própria redação do $\$ 3^{\circ}$ do artigo 48 da Lei de Licitações, que, repita-se, não teve a intenção de estabelecer leilão entre os licitantes, que, já conhecedores das propostas de preços uns dos outros, apresentariam novas propostas, com valores mais baixos. Poder-se-ia argumentar que, neste caso, a Administração Pública seria beneficiada. Contudo, este não é e não foi o objetivo do legislador quando da inserção do $\$$ $3^{\circ}$ no artigo 48 da Lei de Licitações, uma vez que se pretendeu, isto sim, garantir a celeridade, eficiência e economicidade do procedimento licitatório, dentro de uma lógica de moralidade a boa-fé, ${ }^{18}$ que não pode estar desvirtuada da intenção inicial dos licitantes, quando da apresentação de suas propostas de preços, mormente para atender a interesses secundários da Administração Pública.

Confira-se, no sentido do que aqui se sustenta, o entendimento de SIDNEY BITTENCOURT:

"Verificada a existência de falhas em todas as propostas, tem-se a desclassificação de todas as propostas dos licitantes, com a conseqüente extinção do procedimento licitatório. Objetivando a chamada 'economia processual', é facultado à Administração, avaliando as conseqüências de instauração de novo processo, fixar o prazo de oito dias úteis para que os licitantes apresentem novas propostas 'escoimadas' das causas que ocasionaram a desclassificação.

Nesse ponto aflora nova situação que tem causado embaraços às comissōes de licitação: a permissão que a lei oferece contempla a possibilidade de alteração de outro aspecto da proposta que não seja aquele causador do defeito? É inconteste que não. A norma apenas assegura aos licitantes escoimar, isto é, 'livrar de defeitos' as propostas. So-

\footnotetext{
18 A respeito da aplicaçāo do princípio da moralidade, sob a vertente da boa-fé, nus processos administrativos, traz-se à colação as palavras de Egon Bockmann Moreira: "Na relação de administraçãoo o princípio da boa-fé consubstancia dever de comportamento leal e honesto. Nāo basta mero cumprimento impensado e automático da letra da iei. Muito menos seria possivel a burla à moralidade, através de interpretaçāo legal de má indole.

$[\ldots]$

A boa-fé impōe a supressão de surpresas, ardis ou armadilhas. Ao contrário, a conduta administrativa deve guiar-se pela estabilidade, transparência e previsibilidade. Não se permite qualquer possibilidade de engodo - seja direto e gratuito; seja indireto, visando à satisfafão de interesse secundário da Administração. Nem tampouco poderá ser prestigiada juridicamente a conduta processual de má-fé dos particulares. Ambas as partes (ou interessados) no processo devem orientar seu comportamento, endo e extraprocessual, em atenção à boa-fé. Caso comprova a má-fé, o ato (ou o pedido) será nulo, por violação à moralidade administrativa" (Processo Administrativo - Princípios Constitucionais e a Lei 9.784/1999. 2. ed. São Paulo: Malheiros, 2003, p. 107-108).
} 
mente lhes é permitido afastar das propostas a causa de sua desclassificação, nada além disso." ${ }^{19}$ Grifamos.

No mesmo sentido, ao que parece, se posiciona MARIA SYLVIA ZANELLA DI PIETRO:

"Há que se observar que o art. $48, \$ 3^{\circ}$, deve ser interpretado em seus estritos limites: ele não permite a substituição integral de uma proposta por outra; ele apenas permite que o vício que levou à inaceitabilidade seja corrigido naquele ponto específico. A mesma exigência se faz independentemente de ser um só o proponente ou serem vários. De outra forma, estariam sendo burlados os prejuízos da licitação." ${ }^{20}$

Por fim, cumpre dizer que, apesar de a matéria aqui tratada ser extremamente controvertida, há decisão judicial no sentido do que se defende neste trabalho, isto é, concluindo pela possibilidade de apresentação de nova proposta de preços somente no caso de o vício estar a ele direta ou indiretamente ligado. Ao contrário, se a Comissão de Licitação estiver diante de meros erros materiais nas propostas desclassificadas, deve-se permitir aos licitantes tão-somente a possibilidade de escoimá-los, sem, contudo, a faculdade de apresentação de novos preços. Confira-se, assim, a decisão proferida pelo Egrégio Tribunal Regional Federal da 4 Região:

“ADMINISTRATIVO. LICITAÇÃO. CONTRATO ADMINISTRATIVO.

- À vista do art. 48, da Lei $n^{0} 8.666 / 93$, com a redação da Lei $n^{2}$ $8.883 / 94$ e a remuneração da Lei $n^{9} 9.648 / 98$, sendo desclassificadas todas as propostas, a Administração pode autorizar a apresentação de outras escoimadas dos vícios determinantes da desclassificação, quais sejam o descumprimento das exigências do ato convocatório da licitação ou a pretensão de preços excessivos ou manifestamente inexeqüíveis, mas isso não significa, em absoluto, faculdade de apresentação de proposta inteiramente nova, que vá além da correção dos aludidos defeitos.

\footnotetext{
19 BITTENCOURT, Sidney. Licitação Passo a Passo. 4. ed. Rio de Janeiro: Temais \& Idéias Editora, 2002, p. 263-264. Ao que parece, em sentido contrário, apresenta-se a doutrina de Jessé Torres Pereira Júnior, apesar de, na premissa maior, estar de acordo com a distinção entre vícios que afetam ou não o preço da proposta. Confira-se: “A nova proposta dos desclassificados limitar-se-á a alterar os itens motivadores da desclassificaçāo, permanecendo válidos todos os demais da proposta anterior? Questāo intrincada. Nas ediçôes anteriores, registrei o entendimento de que as novas propostas somente poderiam emendar o vício gerador da desclassificaçāo. Mas e se este vicio for o preço (excessivo ou inexequivel) ou, não o sendo, afetá-lo reflexamente? Parece-me, agora, que qualquer que seja o vício emendável, dever-se-ia admitir que os licitantes reapresentassem propostas reformuladas inclusive quanto ao preço. Seria o único meio de conciliar-se o princípio da competitividade com o do sigilo das propostas." Comentários à Lei de Licitações e Contratações da Administração Pública. 6. ed. Rio de Janeiro: Renovar, 2003, p. 502.

20 DI PIETRO, Maria Silvia Zanella. Temas Polêmicos sobre Licitações e Contratos. 5. ed. São Paulo: Malheiros, 2005, p. 232.
} 
- Inexistindo pedido no sentido de ser realizado novo certame, o ato sentencial revela-se 'extra petita'. Grifamos. (TRF da 4 $4^{\underline{a}}$ REGLÃO. AMS - APELAÇÃO EM MANDADO DE SEGURANÇA - 76794. Processo: 199970000305854/PR. Órgão Julgador: QUARTA TURMA. Rel. JUIZ VALDEMAR CAPELETTI. Data da decisão: 7-3-2002. Pub. DJU. DATA: 27-3-2002, p. 261)..$^{21}$

Por fim, cabe argumentar que a faculdade encerrada à Comissão de Licitação pelo artigo $48, \$ 3^{\circ}$, da Lei Federal $n^{\circ} 8.666 / 93$ é plenamente compatível à modalidade licitatória do pregão, por aplicação subsidiária, nos termos permitidos pelo artigo $9^{\circ}$ da Lei Federal $n^{\circ} 10.520 / 02$, cabendo ao Pregoeiro, porém, analisar a fase em que o procedimento do pregão se encontra para, então, à luz da noção de ra-

21 Mencione-se, em sentido contrário, o entendimento firmado pelo Egrégio TRF da $1^{2}$ Região: "ADMINISTRATIVO. LICITAÇÃO. FORMULAÇĀO DE NOVAS PROPOSTAS APÓS DESCLASSIFICAÇĀO GERAL DE TODOS CONCORRENTES. ART. $48 \$ 3^{\circ}$ DA LEI 8.666/93. PARÂMETROS QUE NĀO SE RESTRINGEM À CAUSA ENSEJADORA DA DESCLASSIFICAÇÃO INICIAL PELO PODER PÚBLICO. POSSIBILIDADE DE ALTERAÇĀO DE OUTROS ITENS QUE OS LICITANTES ENTENDEREM PERTINENTES. SELEÇÃO DA PROPOSTA MAIS VANTAJOSA À ADMINISTRAÇÃO. FINALIDADE PRECÍPUA DA ADMINISTRAÇÃO. CAPUT DO ART. 3ํ DA LEI 8.666/93. FORMULAÇĀO DE CONSULTAS PERANTE A COMISSÃO DE LICITAÇĀO A FIM DE ESCLARECER DÚVIDAS. NĀO DIVULGAÇĀO DA RESPOSTA AO QUESTIONAMENTO FORMULADO POR UMA DAS LICITANTES. INEXISTÊNCIA DE VIOLAÇĀO AO PRINCÍPIO DA PUBLICIDADE. DIREITO DE PETIÇĀO INERENTE A TODOS OS CONCORRENTES. FACULDADE NÃO EXERCIDA PELA PARTE.

1. As modificaçōes promovidas na formulação de novas propostas pelos licitantes em virtude do prazo de 8 (oito dias) conferido pela Administração Pública, com fundamento no $\$ 3^{\circ}$ do artigo 48 da Lei $8.666 / 93$, ante a inabilitaçāo de todas as propostas inicialmente apresentadas, poderāo abranger não somente as causas ensejadoras da desclassificação, mas também outros itens que os licitantes entenderem pertinentes, ainda que influam decisivamente na estipulação do preço final ofertado.

2. Tal entendimento coaduna-se com a finalidade precípua da licitação, que é a seleção da proposta mais vantajosa à Administração, com observância do princípio da isonomia, conforme dispōe o caput do artigo $3^{\circ}$ da Lei 8.666/93.

3. A constatação nos autos de que a impetrante/agravada promoveu modificaçōes em sua nova proposta, alterando preços relativos às despesas administrativas/operacionais e lucro, e não somente quanto ao descumprimento das normas trabalhistas relativas ao adicional noturno, causa da inabilitação da primeira proposta pela Comissão de Licitação, conduz à conclusão de que a empresa tinha conhecimento da possibilidade de efetuar alteraçōes em outros itens da proposta financeira.

4. A formulação de consultas perante a Comissão de Licitação com vistas ao esclarecimento de dúvidas é prática rotineira em procedimentos licitatórios, não importando violação ao princípio da publicidade a ausência de divulgação da resposta apresentada pela Administração em virtude de questionamento suscitado por apenas um dos licitantes.

5. Se a impetrante/agravada preferiu não fazer uso do direito de petiçāo inerente a todos os licitantes é porque não teve dúvidas quanto aos parâmetros para elaboraçāo da nova proposta, tanto que afastou não somente a causa que acarretou a desclassificação da primeira proposta, mas também promoveu modificaçōes em outros itens que entendeu necessários, a fim de sagrar-se vencedora no certame, o que, ao final, inocorreu.

6. Agravo de instrumento da Uniăo Federal provido" (AG 2004.01.00.025352-1/DF, QUINTA TURMA. Rel. Desembargadora Federal SELENE MARIA DE ALMEIDA, Julg. 5-11-2004. Pub. 25-11-2004, $D J$ p. 47). Esclarece-se ao leitor que a pesquisa de jurisprudência do Poder Judiciário, modestamente realizada para a feitura deste ensaio, encontrou, especificamente sobre o tema, apenas as duas decisões aqui reproduzidas. 
zoabilidade, facultar a todos os licitantes a possibilidade de escoimar vícios sanáveis das propostas comerciais, desde que nāo desnature a proposta original.

\section{Conclusōes}

Como conclusōes das idéias defendidas neste trabalho pode-se dizer que o artigo 48, $\$ 3^{\circ}$, da Lei Federal $n^{\circ} 8.666 / 93$ não padece de qualquer inconstitucionalidade, eis que não viola os princípios da moralidade administrativa, da isonomia $e$ da competitividade. Ao contrário, além de respeitar e dar efetividade aos princípios antes mencionados, atende, também, aos princípios da razoabilidade, do formalismo moderado, economicidade, eficiência e do aproveitamento dos atos válidos que compöem $o$ procedimento licitatório.

A aplicação do $\$ 3^{\circ}$ do artigo 48 da Lei de Licitações é facultativa ao administrador público, que deverá decidir, diante do caso concreto, de forma motivada, ponderando os critérios de conveniência e oportunidade.

Em havendo desclassificação de todas as propostas, podem ser diversas as consequiências para os licitantes, caso o fundamento do ato administrativo esteja contido no inciso I ou no inciso II do artigo 48 da Lei Geral de Licitações. Estando o ato de desclassificação fundamentado no inciso I (quando as propostas estiverem eivadas de meros erros materiais), e os erros não afetarem os preços ofertados pelos licitantes, não será permitida a alteração dos preços antes oferecidos. Todavia, nos casos dos incisos I e II, poderão os licitantes apresentar novas propostas de preços, contendo novos valores, se os vícios apresentados os afetarem direta ou indiretamente.

Reitera-se que as soluções acima encontradas se amoldam aos princípios da isonomia, da celeridade, da razoabilidade, da economicidade e do aproveitamento dos atos procedimentais lícitos, desde que interpretados sem formalismos exacerbados, que, em última análise, acabam por desvirtuar a idéia de obediência ao procedimento formal.

Para que se tenha uma Administração Pública voltada para a eficiência é necessário, na medida do possível e desde que não afete a legalidade, dar efetividade à idéia de desburocratização.

\section{Bibliografia}

BINENBOJM, Gustavo. Da Supremacia do Interesse Público ao Dever de Proporcionalidade. Um Novo Paradigma para o Direito Administrativo. Direito Administrativo - Série Direito em Foco. (Coord.). Valter Shuenquener de Araújo. Niterói: Ímpetos, 2005.

BITTENCOURT, Sidney. Licitação Passo a Passo. 4. ed. Rio de Janeiro: Temais \& Idéias Editora, 2002. 
CARVALHO FILHO, José dos Santos. Processo Administrativo. Direito Administrativo. Coord. Valter Shuenquener de Araújo. Niterói: Ímpetos, 2005. Série Direito em Foco.

DI PIETRO, Maria Silvia Zanella. Temas Polêmicos sobre Licitações e Contratos. 5. ed. São Paulo: Malheiros, 2005.

FERRAZ, Sérgio; DALLARI, Adilson Abreu. Processo Administrativo. 1. ed. $2^{\underline{a}}$ tiragem. São Paulo: Malheiros, 2002.

JUSTEN FILHO, Marçal. Curso de Direito Administrativo. São Paulo: Malheiros, 2005.

.Comentários à lei de licitaçôes e contratos administrativos. 9. ed. São Paulo: Dialética, 2002.

LEITE, Fábio Barbalho. A mitigação do formalismo no julgamento da habilitação e das propostas em licitaçōes. Revista de Direito Administrativo - RDA, Rio de Janeiro: Renovar, n² 236, p. 175-204, abr./jun. 2004.

MOREIRA NETO, Diogo de Figueiredo. Direito Administrativo. Coord. Valter Shuenquener de Araújo. Niterói: Ímpetos, 2005. Série Direito em Foco.

. O Futuro das Cláusulas Exorbitantes nos Contratos Administrativos. Revista de Direito da Associação dos Procuradores do Novo Estado do Rio de Janeiro: Parcerias Público Privadas. Coord. Flávio Amaral Garcia. Rio de Janeiro: Lumen Juris, 2005. v. 17.

MOREIRA. Egon Bockmann. Processo Administrativo: Princípios Constitucionais e a Lei 9.784/1999. 2. ed. São Paulo: Malheiros, 2003.

OLIVEIRA, Cláudio Eduardo Regis de. Administração Gerencial \& a Reforma Administrativa no Brasil. Curitiba: Juruá, 2002.

PEREIRA JÚNIOR, Jessé Torres. Comentários à Lei de Licitações e Contratações da Administração Pública. 6. ed. Rio de Janeiro: Renovar, 2003.

. Notas Acerca das Repercussōes do Novo Código Civil sobre os Contratos Administrativos. Direito Administrativo. Coord. Valter Shuenquener de Araújo, Niterói: Ímpetos, 2005. Série Direito em Foco.

SOUTO, Marcos Juruena Villela. Direito Administrativo Contratual. Licitações e Contratos Administrativos. Rio de Janeiro: Lumen Juris, 2004.

SIMÕES, Mônica Martins Toscano. O Processo Administrativo e a Invalidade de Atos Viciados. São Paulo: Malheiros, 2004. v. 10. Coleção Temas de Direito Administrativo.

SUNDFELD, Carlos Ari. O Formalismo no Procedimento Licitatório. Revista da Procuradoria Geral da República, nº 5, São Paulo. 